\title{
SPIRITUAL-EMOTIONAL WRITING THERAPY PADA SUBJEK YANG MENGALAMI EPISODE DEPRESIF SEDANG DENGAN GEJALA SOMATIS
}

\author{
Yudi Kurniawan, Retno Kumolohadi \\ Program Magister Psikologi Profesi \\ Fakultas Psikologi dan Ilmu Sosial Budaya \\ Universitas Islam Indonesia, Jl. Kaliurang 14,4 Besi, Sleman, Yogyakarta \\ kurniawan.yudika@gmail.com
}

\begin{abstract}
This study aims to determine the effect of spiritual-emotional writing therapy toward person with moderate depressive diagnosis. This study involved 20 -year-old student with a moderate depressive episode as a subject. Precipitating of her disorder is the events of pramarriage pregnancy in 2012. Data were collected by interview and observation method Quantitative scale. Depression scores were measured using a scale of HDRS (Hamilton Depressive Rating Scale) and obtained a score of 20 (Depressive were heading severe). Intervention is provided by Spiritual Writing Therapy which is a modification of the technique Cognitive Behavior. Islamic spiritual element attached in the form of reflection of gratitude (adaptation emotional) of all the painful events experienced by the subject. Data were analyzed by comparing the state of mind and behavior of the subject between the situation before and after the intervention. The results showed that therapeutic writing attached with cognitive behavioral approach is able to reconstruct the thinking and behavior of the subject, so as to be positive in looking at ourselves and the world around
\end{abstract}

Keywords:gratitude, moderate depressive disorder, spiritual-emotional writing therapy,

\begin{abstract}
Abstrak
Penelitian ini bertujuan untuk melihat pengaruh terapi menulis spiritual-emosional terhadap subjek yang mengalami gangguan depresif sedang. Subjek dalam kasus ini adalah mahasiswi berusia 20 tahun dengan diagnosis episode depresif sedang. Pencetus gangguan adalah peristiwa kehamilan di luar nikah pada tahun 2012. Tujuan intervensi psikologi dalam kasus ini adalah menghilangkan pikiran negatif pada subjek dan mengajarkan perilaku adaptif agar mampu berfungsi kembali di kehidupan sosial. Data dikumpulkan dengan metode observasi wawancara dan skala kuantatif. Skor depresi diukur dengan menggunakan skala HDRS (Hamilton Depressive Rating Scale) dan diperolah skor 20 (Depresif sedang menuju berat). Intervensi yang diberikan adalah Spiritual Writing Therapy yang merupakan modifikasi dari teknik Cognitive Behavior. Unsur spiritual Islam dilekatkan dalam bentuk refleksi syukur (adaptasi emosi) terhadap seluruh peristiwa menyakitkan yang dialami oleh subjek. Data hasil penelitian dianalisis dengan membandingkan kondisi pikiran dan perilaku subjek antara situasi pra dan pasca intervensi. Hasil penelitian menunjukkan bahwa terapi
\end{abstract}


menulis yang dilekatkan dengan pendekatan kognitif perilaku mampu merekonstruksi pikiran dan perilaku subjek, sehingga mampu lebih positif dalam memandang diri dan dunia sekitarnyasa

Kata kunci: episode depresif sedang,kebersyukuran, terapi menulis spiritual-emosi

\section{Pendahuluan}

Episode depresif adalah gangguan suasana perasaan (mood disorder) yang gejalanya meliputi ranah emosional, motivasi, perilaku, fisik, dan kognitif. Pengalaman emosional individu yang mengalami depresi biasanya terbatas pada emosi negatif yang sering dideskripsikan sebagai kesedihan, hilangnya harapan, kesengsaraan, dan hilangnya kegembiraan (Davey, 2008). Sebagian besar individu dengan gangguan depresi memiliki episode kesedihan dan perilaku menangis yang terjadi secara berkala. Sebagian kecil individu dengan gangguan depresi yang dilaporkan pernah merasakan emosi positif. Individu dengan gangguan depresi menunjukkan wajah minim ekspresi positif dan kehilangan minat terhadap kesenangan/humor (Sloane, Strauss \& Wisner, 2001; Davey, 2008).

Depresi sangat berkaitan dengan emosi. Emosi merupakan kompleksitas perasaan yang meliputi psikis, somatis, dan perilaku yang berhubungan dengan afek dan mood. Emosi merupakan perasaan yang dihayati dalam kesadaran, sedangkan afek ditujukan untuk dorongan-dorongan yang lebih mendalam, baik sadar maupun tidak disadari. Sementara mood merupakan subjektivitas emosi yang dapat disampaikan oleh individu dan terobservasi oleh orang lain, misalnya perilaku marah (Ismail \& Siste, 2013).

Individu dalam keadaan mood depresi memperlihatkan kehilangan energi dan minat, perasaan bersalah yang besar, sulit konsentrasi, perubahan perilaku makan yang signifikan, dan berpikiran untuk bunuh diri. Gejala lain adalah perubahan aktivitas, kognitif, verbal, ritme tidur, dan ritme biologis yang lain. Gangguan ini hampir selalu menghasilkan hendaya dalam hubungan interpersonal, sosial, dan fungsi pekerjaan (Ismail \& Siste, 2013).

Gangguan depresi memiliki prevalensi penderita seumur hidup sebesar 15 persen. Penderita dengan jenis kelamin wanita mencapai 25 persen, dua kali lebih banyak daripada laki-laki. Diduga karena adanya perbedaan hormonal, pengaruh melahirkan, perbedaan stressor psikososial, serta model perilaku yang dipelajari tentang ketidakberdayaan. Rata-rata usia penderita depresi adalah 40 tahun, dengan rentang dari usia 20 hingga 50 tahun. Gangguan depresi berat juga dapat muncul pada masa anak dan lanjut usia. Gangguan depresi berat pada usia kurang dari 20 tahun kemungkinan besar berhubungan dengan penggunaan alkohol (Ismail \& Siste, 2013).

Gangguan depresi dapat dipicu oleh faktor biologis, psikososial/faktor lingkungan, seperti peristiwa yang menimbulkan pengaruh emosi negatif mendalam. Pada individu yang mengalami episode depresi untuk pertama kali (memiliki gejala depresi dan terjadi selama minimal 2 minggu), ada tendensi untuk mengalami gangguan depresif berulang di masa yang akan datang. Ada korelasi yang kuat antara penyakit medis kronis dan peningkatan prevalensi gangguan depresi. Orang-orang dengan riwayat penyalahgunaan alkohol 
dan atau obat-obatan juga rentan mengalami gangguan depresi.

Sebanyak sembilah puluh tujuh persen individu dengan gangguan depresi mengeluhkan adanya penurunan energi di tubuh yang menyebabkan mereka kesulitan untuk menyelesaikan tugas dalam fungsinya di lingkungan keluarga, pendidikan, dan/ atau pekerjaan. Sekitar delapan puluh persen individu dengan gangguan depresi mengalami gangguan tidur, seperti terbangun pada tengah malam, dan kemudian mereka kembali teringat dengan masalahnya. Sebagian besar pasien depresi juga mengalami penurunan nafsu makan dan penurunan berat badan. Namun, beberapa pasien justru mengalami peningkatan berat badan (Kaplan \& Sadock, 1997).

Dobsons dan Dozois

menjelaskan bahwa depresi berat dapat memunculkan gejala psikotik, terutama gejala waham dan halusinasi. Waham dan halusinasi yang muncul umumnya terkait dengan dosa dan perasaan bersalah. Gejala ini akan bertambah berat bila tidak ada dukungan dari orang-orang terdekat. Lebih dari dua pertiga pasien depresi di seluruh dunia yang berpikiran untuk bunuh diri, dan sepuluh hingga lima belas persen dari jumlah tersebut benar-benar menjalankan pemikirannya. Sebagian individu dengan gangguan depresi malah tidak menyadari depresinya dan tidak mengeluhkan suatu gangguan suasana perasaan tertentu. Meski demikian, mereka menunjukkan aktivitas penarikan diri dari keluarga, teman, dan aktivitas sosial yang sebelumnya mereka sukai (Kaplan \& Sadock, 1997).

Berdasarkan hasil diagnose subjek mengalami depresi. Keluhan yang dialami oleh subjek adalah perasaan mudah lelah, kepercayaan diri menurun, merasa pesimis, dan ide bunuh diri. Subjek meyakini dirinya sebagai orang yang tidak berguna. Selain itu, subjek juga sering merasakan pusing, jantung yang berdetak lebih cepat, dan keringat dingin saat harus beraktivitas. Semua gejala tersebut sudah dirasakan selama lebih dari dua minggu. Depresi pada subjek dipicu oleh kejaidan ketika mengalami kehamilan di luar nikah karena berhubungan seksual dengan pacarnya. Subjek tertekan dan menggugurkan kandungannya. Setelah peristiwa tersebut, subjek mulai sering merasakan emosi negatif dan tidak punya minat lagi untuk beraktivitas seperti biasanya. Subjek memiliki pikiran negatif terhadap diri sendiri dan merasa dirinya punya banyak dosa. Berdasarkan autoanamnesa, subjek menjelaskan bahwa saat masih kanak-kanak, subjek selalu merasa tertekan saat ibunya berada di rumah. Ibu tidak mau menerima kesalahan sekecil apa pun yang dilakukan oleh subjek. Jika subjek masih melakukan kesalahan, subjek akan mendapatkan pukulan. Perlakuan yang berbeda dialami oleh kedua adik subjek. Kedua adiknya tidak pernah mendapatkan kekerasan fisik. Ayah subjek tidak pernah melakukan kekerasan fisik padanya, namun menurut subjek, ayahnya cenderung tidak peduli kepada keluarga. Melalui informasi dari neneknya, subjek mengetahui bahwa dia bukanlah anak yang kelahirannya diharapkan. Ibu dan ayah subjek telah melakukan hubungan seksual sejak pranikah. Akibatnya, mereka menikah karena terpaksa. Ibu subjek tidak menerima kondisi tersebut sehingga benci terhadap kelahiran subjek. Sejak kecil subjek terpapar dengan situasi kekerasan. Kondisi tersebut membuat subjek tidak mudah mempercayai lingkungan sekitarnya. Ibu dan ayah subjek berprofesi sebagai Tenaga Kerja Indonesia (TKI) di Taiwan dan Korea Selatan yang pergi secara bergantian. Saat ibu subjek pergi ke Taiwan, subjek mendapati ayahnya selingkuh dengan wanita lain di rumah 
mereka. Sebaliknya saat ayah subjek yang berangkat ke Korea Selatan, subjek mendapati ibunya berselingkuh dengan pria lain.

Salah satu cara yang lazim digunakan untuk mengurangi gejala depresi adalah dengan teknik terapi kognitif-perilaku. Terapi kognitif-perilaku diarahkan kepada modifikasi fungsi pikir, merasa, dan bertindak dengan menekankan peran otak dalam menganalisa, memutuskan, bertanya, berbuat, dan memutuskan sesuatu. Manusia memilik potensi untuk menyerap pemikiran yang rasional dan irasional, dimana pemikiran yang irasional akan menyebabkan munculnya gangguan emosi dan tingkah laku. Subjek diharapkan dapat mengubah perilaku negatifnya ke positif dengan mengubah status pikiran dan perasaan.

Salah satu intervensi yang dapat diberikan untuk mengurani tingkat depresi adalah terapi menulis. Terapi menulis merupakan bagian dari teknik kognitifperilaku. Pennebaker (1997) menyatakan bahwa menulis pengalaman emosional atau menulis peristiwa yang penuh tekanan (stressful events) telah menjadi kajian yang menarik banyak peneliti. Beberapa penelitian laboratorium telah mempelajari kegunaan menulis atau berbicara mengenai pengalaman emosional. Menghadapi atau berkonfrontasi dengan isu-isu pribadi secara mendalam telah mendapat penemuan akan menghasilkan kesehatan fisik, kesejahteraan subjektif dan tingkah laku adaptif tertentu.

Paez dkk (1999; Pennebaker, 1997) mencatat bahwa menghadapi atau berkonfrontasi dengan peristiwa-peristiwa penuh tekanan dan traumatis yang dilakukan dalam prosedur menulis dilaporkan menghasilkan tingkat yang lebih tinggi dalam kesehatan fisik (misalnya, lebih sedikit mengunjungi fasilitas kesehatan), fungsi fisiologis yang lebih tinggi (misal, reaksi kekebalan tubuh yang lebih baik) dan kesejahteraan psikologis yang lebih tinggi (misal, afek negatif yang lebih rendah dan afek positif yang lebih tinggi). Pennebaker (1997) menyebutkan bahwa akibat menulis mengenai topik tertentu, ternyata berhubungan dengan perbaikan peringkat mahasiswa pada bulan setelah penelitian dilakukan dan mendapatkan pekerjaan baru yang lebih cepat pada tingkat senior.

Pennebaker dan Beall (dalam Baikie \& Wilhelm, 2005; Qonitatin, dkk, 2011) menyatakan bahwa menulis tentang pengalaman traumatis berhubungan dengan peningkatan efek psikologis yang positif dan dalam jangka panjang menurunkan masalah-masalah kesehatan. Proses katarsis yang diperoleh ketika menulis ekspresif pengalaman-pengalaman emosional pada seseorang yang mengalami gangguan depresi akan dapat memberikan keuntungan bagi dirinya untuk menurunkan simtom-simtom yang mengganggu dan meningkatkan kesejahteraan psikologis maupun fisik. Keuntungan ini terutama dapat diperoleh bagi mereka yang memiliki gangguan depresi dalam tingkat yang ringan.

Ekspresif emosional merupakan ekspresi natural dari emosi yang sebenarnya (Pennebaker, 1997). Penyingkapan emosi merupakan proses yang melibatkan perasaan alamiah atau emosi yang sebenarnya dan mengubahnya menjadi bahasa oral atau tertulis (Smyth \& Pennebaker, dalam Graf, 2004; Qonitatin, dkk, 2011). Proses ini dipercaya untuk mengintegrasi proses kognitif dan emosional, penyingkapan emosional memberikan kesempatan untuk meningkatkan insight, self-reflection, dan organisasi perspektif seseorang terhadap masalah daripada hanya sekedar mengeluarkan emosi.

Penelitian-penelitian saat ini menyimpulkan bahwa keuntungan ekspresi 
emosi tidak dibatasi pada ekspresi emosi yang vokal, kesehatan fisik dan psikologis dapat diperoleh melalui penulisan ekspresif tentang pengalaman hidup yang signifikan. Graf (2004; Qonitatin, dkk, 2011) menemukan bahwa hasil bahwa subjek pada kelompok written emotional disclosure memperlihatkan penurunan yang signifikan pada simtom-simtom kecemasan dan depresi; sebaik peningkatan fungsi kehidupan dan kepuasan yang lebih baik dengan tritmen ketika dibandingkan dengan kelompok kontrol.

Menulis merupakan suatu bentuk ekspresi katarsis dan self-help yang telah dipraktekkan selama bertahuntahun. Menurut Riordan, Benjamin Rush menemukan bahwa proses menulis dapat menurunkan tegangan pada pasiennya dan memberikan informasi yang lebih banyak tentang masalah mereka. Adanya penyingkapan emosi yang dialami pada menulis pengalaman emosional dianggap sebagai faktor yang menghasilkan efek teraupetik. Menulis hal-hal yang tidak sampai melibatkan unsur emosi di dalamnya, seperti membuat deskripsi mengenai kegiatan sehari-hari atau deskripsi suatu tempat misalnya, tidak menghasilkan efek yang sama. Mekanisme proses terapeutik menulis pengalaman emosional sebenarnya sama dengan mekanisme terapi-terapi yang lain (Qonitatin, dkk, 2011).

Mekanisme proses terapeutiknya berpusat pada penyingkapan (disclosure) pengalaman-pengalaman emosional. Pengakuan dan penyingkapan diri merupakan proses dasar yang muncul dalam psikoterapi, dan secara alamiah muncul dalam interaksi sosial yang dianggap membawa manfaat secara psikologis dan bahkan mungkin secara fisik dan psikoterapi membutuhkan dalam derajat tertentu penyingkapan diri. (Pennebaker, 1997). Terapi tersebut adalah bersifat direktif atau evokatif, orientasi insight atau behavioral, pasien dan terapis harus bekerja bersama untuk mendapatkan suatu cerita yang koheren yang menjelaskan masalah dan secara langsung maupun tidak untuk menghasilkan suatu penyembuhan. Penyingkapan masalah pribadi mungkin memiliki nilai terapeutik yang menakjubkan dalam dan pada dirinya sendiri.

Salah satu bagian dari terapi ekspresif adalah terapi menulis yang digunakan sebagai media menyembuhan dan peningkatan kesehatan mental (Malchiodi, 2007; Fikri, 2012). Secara umum tujuan dari terapi menulis diantaranya: (1) Meningkatkan pemahaman bagi diri sendiri maupun orang lain dalam bentuk tulisan dan literatur lain; (2) Meningkatkan kreatifitas, ekspresi diri dan harga diri; (3) Memperkuat kemampuan komunikasi dan interpersonal; (4) Mengekspresikan emosi yang berlebihan (katarsis) dan menurunkan ketegangan, dan (5) Meningkatkan kemampuan individu dalam menghadapi masalah dan beradaptasi (Davis, 1990; Fikri, 2012).

Penelitian sebelumnya membuktikan bahwa menulis pengalaman emosional mempunyai manfaat yang besar sebagai alat terapeutik dalam beberapa permasalahan klinis. Penelitian yang dilakukan oleh O'Connor, dkk, 2003 dan Fikri, 2012 membuktikan bahwa terapi menulis mampu meningkatkan perawatan diri bagi individu yang mengalami kesedihan mendalam karena menulis digunakan sebagai media untuk membuka diri sehingga individu tersebut lebih mampu untuk melakukan rawat diri dengan lebih baik. Penelitian tentang terapi menulis yang dilakukan oleh Baikie dan Wilhelm (2006), Fikri, 2012) membuktikan bahwa terapi menulis dinilai baik dan bermanfaat oleh para peserta karena mampu mengurangi kecemasan dan perbaikan suasana hati. 
Prinsip dasar terapi menulis spiritual emosional sama dengan terapi menulis pengalaman ekspresif/emosional. Subjek diminta untuk menyampaikan bagaimana perasaanya melalui tulisan dan kemudian merefleksikannya. Terapi menulis spiritual emosional melibatkan refleksi pengalaman di masa lalu, masa kini, dan masa depan. Sepanjang rentang tersebut, subjek akan diminta untuk menuliskan apa saja hal menyenangkan yang telah ia dapatkan dan apa saja hal traumatis yang terjadi pada dirinya. Sisi spiritual digali dengan cara merefleksikan hubungan antara pengalaman emosional dan keyakinan subjek terhadap Tuhan yang mengatur segala kehidupannya.

Penanganan kasus depresi yang dialami oleh subjek ini menggunakan terapi kognitif perilaku (Cognitivr Behavioral Therapy). Meta analisis dan studi literatur mengungkapkan bahwa penggunaan Terapi kognitif-perilaku sebanding dengan dampak penggunaan obat-obatan medis dalam mereduksi gejala depresi. Terapi kognitifperilaku juga efektif digunakan pada subjek dengan episode depresi dan depresi berulang. Pada subjek dengan gangguan depresi tidak khas (atypical depression), efektivitas Terapi kognitif-perilaku sebanding dengan fungsi monoamine oxydase inhibitor (MAOI). MAOI adalah senyawa kimia yang menghambat aktivitas enzim monoamine oksidase dan lama digunakan sebagai obat antidepressan (O'Hea. et.al, 2008).

Adanya pemikiran rasional dan irasional yang berkaitan erat menjadikan manusia menjadi tidak sempurna sehingga muncul terapi kognitif-perilaku. Pada intinya terapi kognitif-perilaku berusaha menolong individu agar dapat menerima dirinya sebagai makhluk yang akan selalu berbuat kesalahan tetapi pada saat yang bersamaan juga tumbuh sebagai orang yang bisa belajar hidup damai dengan diri sendiri.
Terapi kognitif-perilaku secara eksplisit menekankan bahwa manusia memiliki kemampuan untuk berpikir dan bertindak secara simultan.

Dalam terapi kognitif-perilaku, kognitif subjek dimodifikasi dengan dua cara: secara langsung melalui intervensi kognisi dan secara tidak langsung melalui intervensi perilaku yang tampak. Proses mengubah perilaku kita dengan maksud mengubah apa yang kita pikirkan adalah strategi yang efektif untuk menghemat waktu dalam proses mengubah sikap. Meichenbaum (Spiegler \& Guevremont, 2010) menyatakan pendekatan Cognitive Behavior Therapy merupakan pendekatan terapeutik yang memodifikasi pikiran, asumsi, dan sikap yang ada pada individu. Terapi kognitif perilaku pada dasarnya meyakini bahwa pemikiran manusia terbentuk melalui proses rangkaian stimulus, kognitif, dan resposn, saling berkait dan membentuk semacam jaringan dalam otak manusia. Proses kognitif akan menjadi faktor penentu dalam menjelaskan bagaimana manusia berpikir, merasa dan bertindak. Teknik self-instructional training, yang digunakan untuk melatih individu agar secara efektif dalam beradaptasi dan menyelesaikan masalah dalam situasi sulit.

Menurut Spiegler \& Guevremont, (2010) teknik terapi kognitif perilaku terbagi atas intervensi kognitif dan intervensi perilaku yang tampak. Teknik-teknik yang digunakan adalah penangkapan pemikiran (thought catching) yang mempunyai dasar bahwa hubungan antara pikiran, perasaan, dan perilaku dapat ditunjukkan dengan merekam dan memunculkan pikiran, perekaman dan pemunculan pikiran sudah dengan sendirinya ikut membantu memecahkan ikatan antara pikiran dengan perasaan dengan membuat pikiran menjadi nampak kurang realistik. Perekaman dan pemunculan pikiran, maka terapis dan subjek 
memperoleh data untuk memformulasikan hipotesis yang akan dimanfaatkan untuk testing realitas.

Tujuan dari penangkapan pikiran adalah untuk menghilangkan pikiran maladaptif sebagai penyebab kecemasan yang dialami subjek. Penangkapan pikiran dilakukan dengan cara menjelaskan pada subjek mengenai adanya keterkaitan erat antara pikiran, perasaan, dan perilaku. Subjek diminta untuk menangkap pikiran salah yang menguatkan perasaan cemasnya dan menyebabkan reaksi yang tidak diharapkan. Hal ini dilakukan guna meningkatkan kesadaran pada subjek terhadap pikirannya yang salah.

Teknik yang dugunakan adalah testing realita. Tujuan dari teknik ini adalah mencari bukti - bukti yang mendukung atau menggugurkan asumsi dari pikiran maladaptif subjek. Testing realitas dilakukan dengan cara mengidentifikasi pikiran atau pernyataan yang dibuat oleh subjek, bersifat negatif, atau berhubungan dengan perasaan yang mengganggu. Teknik testing realita menuntut subjek untuk bercerita mengenai keyakinannya secara perlahan dengan mencari bukti - bukti yang mendukung atau menggugurkan pernyataan subjek yang tidak sesuai dengan keadaan yang sebenarnya. Teknik yang digunakan dalam pendekatan ini adalah generating alternative Interpretations, yaitu teknik intervensi kognitif yang merestruktur cara berpikir dengan kalimat negatif menjadi kalimat yang lebih positif/adaptif. Terapis pada awalnya membuat Generating Alternative Interpretations pada kasus kecemasan atau depresi dan kemudian subjek mengulang sendiri teknik tersebut. Teknik lainnya yaitu activity schedule. Activity schedule adalah rencana/catatan tertulis terkait aktivitas harian yang harus dilakukan oleh subjek. Teknik ini sangat berguna pada subjek yang memiliki kecemasan dan depresi. Subjek dan terapis secara bersama-sama merancang aktivitas harian subjek dalam rentang waktu tertentu (misalnya selama dua pekan). Rencana aktivitas tersebut menyediakan ruang bagi subjek untuk melakukan sesuatu yang produktif. Pada subjek dengan kasus depresi, seringkali terjadi hambatan besar bahkan untuk sekadar melakukan aktivitas sederhana sekalipun. Rencana aktivitas ini menjadi struktur yang membantu subjek untuk aktif terlibat dan beraktivitas sepanjang hari.

Teknik lain dalam terapi menulis yaitu mastery and pleasure rating. Pada subjek depresi, yang dibutuhkan tidak hanya sekadar aktivitas, namun juga perasaan kompeten dan mampu terhadap apa yang mereka lakukan. The Mastery and Pleasure Technique menyediakan ruang bagi subjek untuk merasakan bahwa dirinya mampu dan bisa menikmati aktivitas tersebut dalam bentuk rating. Subjek memberikan rating 0-5 pada aktivitas yang mereka lakukan. Rating 0 untuk menggambarkan ketidakmampuan/tidak menikmati aktivitas dan ratig 5 menggambarkan sangat mampu/ sangat menikmati aktivitas.

\section{Metode Penelitian}

Penelitian ini menggunakan rancangan dengan desain A-B follow up (Barlow dan Hersen, 1984; Rosdaniar, 2012). Desain A-B merupakan desain dasar dari penelitian eksperimen tunggal (Sunanto, 2005; Rosdaniar, 2012). Prosedur utama yang ditempuh dalam desain A-B-follow up meliputi pengukuran kondisi target pada fase baseline dan kemudian diberikan intervensi. Selama fase intervensi, kondisi subjek secara berkelanjutan dilakukan pengukuran dan follow up (Lovaas, 2003; Sunanto, 2005; Rosdaniar, 2012). 
A -B - Follow Up

Keterangan:

$\mathrm{A}=$ baseline, $\mathrm{B}=$ intervensi/treatment

Pelaksanaan penelitian terdiri atas fase baseline (A), fase intervensi (B) dan fase follow up (tindak lanjut). Rancangan penelitian A-B dengan follow up bertujuan untuk mengevaluasi apakah perubahan perilaku yang terjadi bersifat menetap atau hanya sementara (Barlow dan Hersen, 1984; Rosdaniar, 2012). Hasil baseline, intervensi dan follow up kemudian dibandingkan, untuk mengetahui efek pemberian intervensi berupa terapi menulis spiritual emosional. Intervensi dilakukan dalam tiga sesi. Sesi satu, berupa materi thought catching yang menuntut subjek untuk mengenali pikiran negative yang dimiliki. Sesi kedua berupa materi testing realita, dalam tahap ini subjek diminta untuk menuliskan bukti-bukti pekiran negative yang dimiliki dan tahap ke tiga, berupa materi pemberian afirmasi dan konteks spiritual.

Tabel. 1 Tahapan Intervensi

\begin{tabular}{lll}
\hline No & Sesi & Materi \\
\hline 1 & Pertama & Thought catching, subjek diarahkan \\
& & untuk mengenali pikiran-pikiran \\
& & negatif yang selama ini muncul. \\
& Di akhir sesi, subjek diminta \\
& untuk menuliskan pengalaman dan \\
& perasaan yang dirasakan setelah \\
& sesi tersebut. \\
& Testing realita, subjek diberikan \\
& lembar kerja untuk menuliskan \\
& apakah benar-benar ada bukti atas \\
& pikiran negatif yang dia rasakan. Di \\
& akhir sesi, subjek kembali diminta \\
& untuk menuliskan pengalaman dan \\
& perasaan yang dirasakan setelah \\
& sesi tersebut berakhir. \\
& Pemberian afirmasi dan konteks \\
& spiritual terhadap materi tulisan \\
& Ketigjek
\end{tabular}

Subjek dalam penelitian ini adalah seorang wanita lajang berusia 22 tahun yang mengalami mengalami trauma akibat kekerasan fisik dan seksual. Subjek adalah seorang mahasiswi perguruan tinggi di Yogyakarta. Skor depresi diukur dengan menggunakan Hamilton Depressive Rating Scale (HDRS). Pemilihan subjek berdasarkan kriteria keunikan kasus yang dialaminya. Subjek pernah mengalami kekerasan fisik oleh ibunya dan pernah mengalami kekerasan seksual saat remaja. Subjek dalam penelitian ini ditentukan dengan teknik purposive sampling, yaitu pemilihan sampel sesuai dengan yang dikehendaki untuk kasus unik dan sulit mengambil sampel serta membutuhkan investigasi mendalam. Subjek yang dipilih adalah orang-orang yang memiliki informasi khusus mengenai kasus yang diteliti (Newman, 2003).

Penelitian ini merupakan penelitian yang dilakukan dengan pendekatan single case method. Riset ini menggunakan 1 orang subjek yaitu wanita yang mengalami trauma akibat kekerasan fisik dan seksual. Menurut Kazdin (2010), singel case method adalah desain penelitian untuk mengetahui efek dari sebuah terapi dengan beberapa subjek dalam satu kelompok atau subjek tunggal. Selain subjek penelitian sebagai sumber data utama, peneliti juga berusaha mencari informan sebagai sumber data sekunder. Informan adalah orang yang mengetahui atau perneh berhubungan dengan subjek dan mengetahui tentang permasalahan yang ingin diteliti. Informan harus bersifat netral atau tidak memiliki kepentingan pribadi untuk menjelek-jelekkan orang lain, dan memilikiinformasi luas terkait masalah yang diteliti (Bungin, 2002; Rosdaniar, 2012). Data dikumpulkan dengan metode self-report, observasi, dan wawancara. Data hasil penelitian dianalisis dengan membandingkan,kondisi pikiran dan 
perilaku subjek antara situasi pra dan pasca intervensi.

\section{Hasil dan Pembahasan}

Berdasarkan pengukuran dengan Hamilton Depressive Rating Scale, subjek memperoleh skor 31 dan masuk kategori sedang menuju berat. Berdasarkan acuan diagnosis PPDGJ, subjek termasuk kategori depresi sedang dengan gejala somatis, yang dapat dilihat pada tabel berikut:

Tabel 2. Pedoman Diagnosis Episode Depresif

\begin{tabular}{|c|c|c|c|}
\hline \multirow[t]{2}{*}{ Pedoman Diagnostik } & \multirow[t]{2}{*}{ Kategori Kasus } & \multicolumn{2}{|c|}{$\begin{array}{c}\text { Keterangan } \\
\text { Terpenuhi }\end{array}$} \\
\hline & & $\mathrm{Ya}$ & Tidak \\
\hline Afek depresif & $\begin{array}{l}\text { Klien kerap sedih, murung, dan bersuara } \\
\text { lirih }\end{array}$ & $\sqrt{ }$ & \\
\hline $\begin{array}{l}\text { Kehilangan minat dan } \\
\text { kegembiraan }\end{array}$ & $\begin{array}{l}\text { Tidak signifikan, subjek masih sering } \\
\text { berkumpul dengan teman-teman } \\
\text { dekatnya }\end{array}$ & & $\sqrt{ }$ \\
\hline $\begin{array}{l}\text { Berkurangnya energi yang } \\
\text { menuju meningkatnya keadaan } \\
\text { mudah lelah (rasa lelah yang } \\
\text { nyata sesudah kerja sedikit saja) } \\
\text { dan menurunnya aktivitas }\end{array}$ & Mudah lelah saat beraktivitas & $\sqrt{ }$ & \\
\hline Gejala lainnya & & & \\
\hline $\begin{array}{l}\text { Konsentrasi dan perhatian } \\
\text { berkurang }\end{array}$ & $\begin{array}{l}\text { Selalu gelisah, susah fokus, dan selalu } \\
\text { merasa bersalah. Klien susah fokus saat } \\
\text { kuliah. }\end{array}$ & $\sqrt{ }$ & \\
\hline $\begin{array}{l}\text { Harga diri dan kepercayaan diri } \\
\text { berkurang }\end{array}$ & $\begin{array}{l}\text { Merasa sangat kecewa terhadap diri } \\
\text { sendiri dan mantan pacarnya. Klien } \\
\text { menjadi peragu dan sangat sulit } \\
\text { mempercayai orang lain. Tidak berani } \\
\text { memulai hubungan interpersonal baru. }\end{array}$ & $\sqrt{ }$ & \\
\hline $\begin{array}{l}\text { Gagasan tentang rasa bersalah } \\
\text { dan tidak berguna }\end{array}$ & $\begin{array}{l}\text { Klien merasa berdosa terhadap } \\
\text { diri sendiri dan orang tua, karena } \\
\text { pengalaman masa lalunya yang pernah } \\
\text { menggugurkan kandungan }\end{array}$ & $\sqrt{ }$ & \\
\hline $\begin{array}{l}\text { Pandangan masa depan yang } \\
\text { suram dan pesimistis }\end{array}$ & $\begin{array}{l}\text { Ia merasa tidak yakin akan mendapatkan } \\
\text { pasangan hidup, tidak yakin akan sukses }\end{array}$ & $\sqrt{ }$ & \\
\hline $\begin{array}{l}\text { Gagasan atau perbuatan } \\
\text { membahayakan diri atau bunuh } \\
\text { diri }\end{array}$ & $\begin{array}{l}\text { Pernah memiliki ide bunuh diri dengan } \\
\text { cara melompat dari atas jembatan }\end{array}$ & $\sqrt{ }$ & \\
\hline Tidur terganggu & Tidak ada perubahan & & $\sqrt{ }$ \\
\hline Nafsu makan berkurang & Tidak ada perubahan dalam pola makan & & $\sqrt{ }$ \\
\hline $\begin{array}{l}\text { Lamanya seluruh episode } \\
\text { berlangsung minimum dua } \\
\text { minggu. }\end{array}$ & $\begin{array}{l}\text { Klien mengalami sejak pertengahan } \\
\text { November tahun } 2013 \text { (Intervensi } \\
\text { dilakukan Maret 2014) }\end{array}$ & $\sqrt{ }$ & \\
\hline
\end{tabular}


Pedoman Diagnostik

Kategori Kasus

Keterangan

Terpenuhi

Ya Tidak

Menghadapi kesulitan nyata

Hambatan dalam kuliah dan interaksi

sosial yang lebih luas

untuk meneruskan kegiatan

sosial, pekerjaan, dan urusan

rumah tangga

Gejala somatis

- Jantung berdetak lebih cepat

- Pusing

- Keringat dingin saat beraktivitas

Subjek mengalami 2 dari 3 gejala utama, 5 gejala lainnya, dan ditambah gejala somatis. Berdasarkan acuan PPDGJ, subjek mengalami episode depresif sedang dengan gejala somatis.

Tabel 3 Baseline Pikiran

\begin{tabular}{lccccccc}
\hline & \multicolumn{7}{c}{ Minggu II Maret 2014 } \\
\cline { 2 - 7 } & Senin & Selasa & Rabu & Kamis & Jumat & Sabtu & Minggu \\
\hline $\begin{array}{l}\text { Pesimis terhadap } \\
\text { masa depan }\end{array}$ & $\sqrt{ }$ & $\sqrt{ }$ & $\sqrt{ }$ & $\sqrt{ }$ & $\sqrt{ }$ & $\sqrt{ }$ & $\sqrt{ }$ \\
$\begin{array}{l}\text { Pikiran bersalah } \\
\text { dan dipersalahkan }\end{array}$ & & $\sqrt{ }$ & $\sqrt{ }$ & $\sqrt{ }$ & $\sqrt{ }$ & $\sqrt{ }$ & $\sqrt{ }$ \\
$\begin{array}{l}\text { oleh lingkungan } \\
\begin{array}{l}\text { Pikiran bunuh diri } \\
\text { Keyakinan bahwa } \\
\text { diri tidak berguna }\end{array}\end{array}$ & $\sqrt{ }$ & $\sqrt{ }$ & $\sqrt{ }$ & $\sqrt{ }$ & $\sqrt{ }$ & $\sqrt{ }$ & $\sqrt{ }$ \\
\hline
\end{tabular}

Berdasarkhasil assessment di dapatkan baseline pikiran pada subjek yaitu adanya pikiran pesimis terhadap masa depan, rasa bersala dan dipersalahkan oleh lingkungan, pikiran untuk bunuh diri dan keyakinan diri tidak berguna dalam minggu kedua. Berdasarkan baseline perilaku, subjek juga mengalami gejala jantung berdebar-debar, berkeringat dingin dan pusing tanpa sebab fisioligis.

Tabel 3 Baseline Perilaku

\begin{tabular}{lccccccc}
\hline & \multicolumn{7}{c}{ Minggu II Maret 2014 } \\
\cline { 2 - 7 } & Senin & Selasa & Rabu & Kamis & Jumat & Sabtu & Minggu \\
\hline Jantung berdebar & $\sqrt{n}$ & $\sqrt{ }$ & $\sqrt{ }$ & $\sqrt{ }$ & $\sqrt{ }$ & $\sqrt{ }$ & $\sqrt{ }$ \\
kencang saat & & & & & & & \\
bangun tidur & & $\sqrt{ }$ & $\sqrt{ }$ & & & $\sqrt{ }$ & \\
$\begin{array}{l}\text { Berkeringat } \\
\text { dingin tanpa sebab }\end{array}$ & & & & & & & \\
fisiologis & & $\sqrt{ }$ & $\sqrt{ }$ & & $\sqrt{ }$ & \\
$\begin{array}{l}\text { Pusing tanpa sebab } \\
\text { fisiologis }\end{array}$ & & $\sqrt{ }$ & & & & & \\
\hline
\end{tabular}




\section{Sesi I}

Berdasarkan hasil asesmen psikodiagnotik pada sesi sebelumnya, subjek cenderung menekan emosi dan pikiran yang muncul. Pada sesi ini, subjek datang dengan dengan tujuan menghilangkan pikiran dan perasaan negatif yang dirasakan terhadap dirinya sendiri. Pada awal sesi, intervensi dilakukan dengan memberikan pertanyaan mengenai skala Stimulus Unit Discomfort (SUD) yang dirasakan oleh subjek saat berkonflik dengan ibunya. Subjek menjawab pada skala 8 (dari skala 0-10, 0 tidak menganggu sama sekali, 10 sangat menganggu).

Psikoedukasi diberikan mengenai kaitan antara pikiran, perasaan, dan perilaku pada subjek. Pada bagian ini terjadi diskusi antara terapis dan subjek mengenai pikiran yang dimiliki oleh subjek. Setelah diskusi intervensi dilanjutkan pada tahap thought catching. Pada bagian ini, subjek, dengan bantuan terapis diminta untuk menelusuri pikiran-pikiran negatif yang selama ini dia rasakan. Terdapat sekitar 6 pikiran dan perasaan negatif yang dimiliki oleh subjek. Terapis meminta 1 pikiran dan perasaan negatif yang paling menganggu untuk diselesaikan sebagai prioritas.

Pikiran yang paling menganggu tersebut adalah pikiran merasa diperhatikan dan diolok-olok saat lewat di hadapan orang banyak. Peneliti masuk pada tahap testing realita, di mana subjek diminta untuk menelesuri situasi yang membuatnya berpikir negatif dan pikiran otomatis yang muncul dalam situasi tersebut. Subjek akhirnya bisa melihat bahwa tidak ada buktibukti yang menguatkan pikiran otomatis negatifnya tersebut. Pada bagian akhir, terapis memberikan teknik stabilisasi point of power yang berguna untuk memberikan penguatan dan energi positif pada subjek. Setelah semua tahap pada sesi 1 selesai, subjek mengatakan SUDnya pada level 5. Terapis memberikan penugasan homework berupa lembar thought catching pada subjek, agar subjek dapat mengidentifikasi pikiran dan emosi negatif yang muncul, untuk dibahas pada sesi berikutnya.

Tabel 4 Thought Catching

\begin{tabular}{|c|c|c|}
\hline $\begin{array}{l}\text { PIKIRAN } \\
\text { NEGATIF }\end{array}$ & PERASAAN & SITUASI \\
\hline $\begin{array}{l}\text { Meyakini dirinya } \\
\text { tidak berguna, } \\
\text { tidak ada orang } \\
\text { yang menyayangi } \\
\text { dirinya }\end{array}$ & $\begin{array}{l}\text { Sedih, } \\
\text { marah, } \\
\text { kecewa }\end{array}$ & $\begin{array}{l}\text { Ibu } \\
\text { memarahi } \\
\text { subjek }\end{array}$ \\
\hline
\end{tabular}

\section{Sesi II}

Sesi kedua dibuka dengan identifikasi SUD subjek yang berada pada level 5. Pada pertemuan ini, subjek diberikan penjelasan mengenai teknik cognitive rehearsal yang berguna untuk mengaktivasi pengalaman positif saat melakukan kegiatan, terutama saat melakukan kegiatan seorang diri. Subjek ternyata masih merasakan beberapa pikiran negatif, sehingga terapis kembali melakukan proses thought catching dan testing realita. Pada tahap akhir, terapis memberikan teknik stabilisasi safe place untuk menciptakan dan memberikan keyakinan pada subjek bahwa ada tempat aman yang bisa kapan pun dia kunjungi. Pada sesi ini, SUD subjek turun pada level 3. Terapis meminta subjek untuk menuliskan semua pikiran dan perasaannya dalam format tabel khusus, yang akan dijabarkan di akhir sesi.

\section{Sesi III}

Pada sesi ketiga, ternyata masih ada pikiran-pikiran negatif yang muncul pada subjek, sehingga terapis meminta subjek untuk menyampaikan terlebih dahulu apa yang sedang dia rasakan. Subjek juga belum mengerjakan tugas cognitive rehearsal, karena subjek belum sempat 
beraktivitas sendiri. Pada waktu satu pekan belakangan, subjek merasa terancam dan terganggu dengan seseorang yang ingin tahu tentang dirinya. Oleh karena itu, subjek tidak berani beraktivitas sendirian. Terapis membantu subjek untuk mengenali potensi positif dirinya dan meminta subjek untuk melakukan hal tersebut dengan tujuan membangkitkan energi positif yang dia miliki. Pada akhir sesi, subjek diberikan homework cognitive rehearsal.

\section{Sesi IV}

Subjek datang ke sesi 4 dengan SUD pada level 4. Subjek sudah melakukan homework cognitive rehearsal dan merasakan ada kesenangan saat melakukan aktivitas seorang diri. Namn subjek masih mengakui bahwa ada banyak perasaan dan pikiran yang dia pendam. Seringkali perasaan dan pikiran tersebut menganggu aktivitasnya. Pada sesi ini, terapis menanyakan kesiapan pada subjek apabila dilakukan sesi tambahan sebagai proses proyeksi perasaan dan pikirannya. Subjek menyatakan bersedia.

Tabel 5 Isi tulisan Subjek

\begin{tabular}{|c|c|c|c|}
\hline Tanggal & Pokok Tulisan & Aspek Emosional & Aspek Spiritual \\
\hline 10 April 2014 & $\begin{array}{l}\text { Entah apa yang aku pikirkan, aku } \\
\text { tak pernah merasa tenang dan } \\
\text { nyaman, seperti ada perasaan } \\
\text { berdosa terhadap apa yang } \\
\text { pernah aku lakukan. Hari-hariku } \\
\text { terasa melelahkan. } \\
\text { Apakah Tuhan masih sayang } \\
\text { padaku? Aku butuh petunjuk } \\
\text { dariNya. Aku takut Tuhan } \\
\text { melupakanku, karena aku juga } \\
\text { sering melupakan Tuhan. }\end{array}$ & $\begin{array}{l}\text { Tidak nyaman } \\
\text { Lelah }\end{array}$ & $\begin{array}{l}\text { - Rasa berdosa } \\
\text { - Mengharap } \\
\text { petunjuk dari } \\
\text { Tuhan }\end{array}$ \\
\hline 15 April 2014 & $\begin{array}{l}\text { Banyak tugas kuliah yang harus } \\
\text { aku selesaikan, sayangnya } \\
\text { aku merasa terlalu lelah untuk } \\
\text { melakukannya. Aku sepertinya } \\
\text { juga harus bekerja untuk } \\
\text { mendapatkan uang jajan. Ibu } \\
\text { tidak pernah lagi memberiku } \\
\text { uang. Kepalaku rasanya pusing } \\
\text { sekali, jantungku juga sering } \\
\text { berdebar kencang. Apa yang } \\
\text { harus aku lakukan. } \\
\text { Mungkin lebih baik aku diam } \\
\text { sejenak, berdoa, dan sholat. }\end{array}$ & $\begin{array}{l}\text { Rasa lelah } \\
\text { Khawatir }\end{array}$ & $\begin{array}{l}\text { Pasrah } \\
\text { Meminta pada } \\
\text { Tuhan }\end{array}$ \\
\hline 20 April 2014 & $\begin{array}{l}\text { Setelah beberapa proses terapi, } \\
\text { aku merasa lebih baik. Aku mulai } \\
\text { mendekatkan diri lagi kepada } \\
\text { Tuhan, semoga Tuhan mau } \\
\text { memaafkan semua dosaku dulu. }\end{array}$ & $\begin{array}{l}\text { Perasaan lebih } \\
\text { baik, positif }\end{array}$ & $\begin{array}{l}\text { Mendekatkan diri } \\
\text { kepada Tuhan }\end{array}$ \\
\hline
\end{tabular}




\begin{tabular}{|c|c|c|c|}
\hline Tanggal & Pokok Tulisan & Aspek Emosional & Aspek Spiritual \\
\hline 25 April 2014 & $\begin{array}{l}\text { Awalnya terasa cukup sulit untuk } \\
\text { memulai ini semua, berubah ke } \\
\text { arah yang lebih positif. Seperti } \\
\text { berjuang melewati masa kritis } \\
\text { karena takut apa yang keluar } \\
\text { dari mulutku akan ditertawakan. } \\
\text { Tapi semua ini akhirnya menjadi } \\
\text { lebih baik ketika aku terus bisa } \\
\text { mengungkapkan perasaan negatif, } \\
\text { tanpa dicap bersalah. } \\
\text { Alhamdulillah... Semuanya atas } \\
\text { kuasa Tuhan juga. Aku ingin } \\
\text { berbagi perasaan bahagia } \\
\text { ini bersama teman-teman. } \\
\text { Setidaknya, dengan mengingat } \\
\text { Tuhan, aku tidak lagi merasa } \\
\text { sedih dan terlupakan. }\end{array}$ & Emosi positif & $\begin{array}{l}\text { Bersyukur } \\
\text { Berbagi } \\
\text { kebahagaiaan }\end{array}$ \\
\hline 30 April 2014 & $\begin{array}{l}\text { Mungkin saat ini aku sedang } \\
\text { bahagia. Lebih bisa merasakan } \\
\text { energi positif mengalir di dalam } \\
\text { diriku. } \\
\text { Aku senang sekali atas semua } \\
\text { perasaan ini. Aku sekarang bisa } \\
\text { menikmati lagi semua kegiatan } \\
\text { yang dulu pernah aku lakukan. } \\
\text { Mungkin dulu Tuhan pernah } \\
\text { marah dengan sikapku, namun } \\
\text { aku yakin, kalau aku mau } \\
\text { berubah, Tuhan pasti akan } \\
\text { memaafkan semua kesalahanku. }\end{array}$ & Bahagia & $\begin{array}{l}\text { Syukur, } \\
\text { Niat bertaubat }\end{array}$ \\
\hline
\end{tabular}

Tabel 6 Kondisi Pikiran Pasca Intervensi

\begin{tabular}{|c|c|c|c|c|c|c|c|}
\hline & \multicolumn{7}{|c|}{ Minggu IV April 2014} \\
\hline & Senin & Selasa & Rabu & Kamis & Jumat & Sabtu & Minggu \\
\hline $\begin{array}{l}\text { Pesimis terhadap } \\
\text { masa depan }\end{array}$ & Tidak ada & Tidak ada & Tidak ada & Tidak ada & Tidak ada & Tidak ada & Tidak ada \\
\hline $\begin{array}{l}\text { Pikiran bersalah } \\
\text { dan dipersalahkan } \\
\text { oleh lingkungan }\end{array}$ & Tidak ada & Tidak ada & Tidak ada & Tidak ada & Tidak ada & Tidak ada & Tidak ada \\
\hline Pikiran bunuh diri & Tidak ada & Tidak ada & Tidak ada & Tidak ada & Tidak ada & Tidak ada & Tidak ada \\
\hline $\begin{array}{l}\text { Keyakinan bahwa } \\
\text { diri tidak berguna }\end{array}$ & Tidak ada & Tidak ada & Tidak ada & Tidak ada & Tidak ada & Tidak ada & Tidak ada \\
\hline
\end{tabular}


Tabel 7 Kondisi Perasaan/Perilaku Pasca Intervensi

\begin{tabular}{lccccccc}
\hline & \multicolumn{5}{c}{ Minggu IV April 2014 } \\
\cline { 2 - 7 } & Senin & Selasa & Rabu & Kamis & Jumat & Sabtu & Minggu \\
\hline $\begin{array}{l}\text { Jantung berdebar } \\
\text { kencang saat } \\
\text { bangun tidur }\end{array}$ & Tidak ada & Tidak ada & Tidak ada & Tidak ada & Tidak ada & Tidak ada & Tidak ada \\
$\begin{array}{l}\text { Berkeringat } \\
\text { dingin tanpa sebab } \\
\text { fisiologis }\end{array}$ & Tidak ada & Tidak ada & Tidak ada & Tidak ada & Tidak ada & Tidak ada & Tidak ada \\
$\begin{array}{l}\text { Pusing tanpa sebab } \\
\text { fisiologis }\end{array}$ & Tidak ada & Ada & Ada & Tidak ada & Tidak ada & Tidak ada & Tidak ada \\
\hline
\end{tabular}

Tabel 6 dan 7 menunjukkan ada perubahan kondisi pikiran dan perilaku subjek dibandingkan dengan situasi sebelum intervensi. Sebelum intervensi, subjek kerap mengalami distorsi pikiran yang membuatnya tidak nyaman dengan diri sendiri. Subjek masih meneruskan aktivitas menulis hingga setelah proses intervensi berakhir. Menurut subjek, tulisan-tulisan yang dibuatnya sangat membantu untuk memetakan pikiran negatif yang kerap muncul dan mengganggu keyakinan subjek terhadap masa depannya.

Berdasarkan hasil asesmen, tampak bahwa pola kepribadian subjek saat ini (usia dewasa) dipengaruhi oleh pembiasaan dari lingkungan dan faktor genetis keluarga. Sejak kecil, ibu mendidik subjek dengan memberikan hukuman fisik dan minim afeksi. Sementara ayah tidak terlalu memperhatikan perkembangan subjek. Kekerasan fisik dan verbal yang diterima subjek dari ibunya menimbulkan trauma psikologis dan kebiasaan memendam perasaan. Subjek tidak terbiasa untuk mengungkapkan emosinya kepada orang lain, karena subjek belajar bahwa pengungkapan emosi akan membuat orang lain tidak menyukainya.

Subjek juga tidak mendapatkan kepercayaan dan rasa aman dari figur lekat terdekatnya (ibu). Subjek menjadikan ibu sebagai sosok yang ditakuti karena kerap memberikan hukuman fisik dan verbal. Saat dewasa, subjek juga menyimpan kemarahan dengan figur ibu karena akumulasi perlakuan ibu yang tidak menyenangkan terhadap subjek. Ketiadaan rasa aman sejak kecil membuat subjek mudah curiga dan tidak mudah percaya dengan orang lain. Subjek menilai orang lain yang mendekatinya hanya akan mengambil keuntungan dari dirinya.

Hasil intervensi menunjukkan bahwa pendekatan kognitif-perilaku dengan teknik menulis spiritual-emosional efektif menghilangkan episode depresif sedang yang dialami oleh subjek. Hasil pengukuran dengan menggunakan skala HDRS pasca intervensi menunjukkan angka 9, yang artinya subjek berada pada level normal. Hal ini sejalan dengan penelitian Smyth (2008; Fikri, 2012) tentang terapi menulis membuktikan bahwa terapi menulis mampu memperbaiki suasana hati dan pertumbuhan yang positif pasca trauma bagi para PTSD, meskipun efek terapinya tidak mampu menurunkan tingkat keparahan gejala PTSD.

Pennebaker (1997) juga menjelaskan bahwa menulis mengenai pengalaman emosional, peristiwa traumatis dan kejadian menekan yang menyebabkan stres atau situasi stressful akan berpengaruh terhadap kesehatan mental seseorang, kemampuan untuk mengelola dan menurunkan stres, mendapatkan insight atau pemahaman, mengurangi keluhan-keluhan fisik, meningkatkan sistem kekebalan tubuh 
bahkan meningkatkan prestasi akademik dan kinerja pekerjaan.

Intervensi pada kasus ini menambahkan unsur emosional-spiritual dalam setiap tulisan yang dibuat oleh subjek. Unsur spiritual dilekatkan sebagai motivasi kepada subjek bahwa semua masalah yang dihadapi manusia bisa diserahkan kepada Tuhan. Adz-Zakiey (2007) menyatakan bahwa motivasi spiritual muncul sebagai manisfestasi fitrah manusia untuk memenuhi kebutuhan ruhaninya. Kebutuhan ruhani antara lain berupa keridhaan, kecintaan, dan harapan yang dipanjatkan kepada Tuhan. Inilah motivasi yang ingin peneliti berikan kepada subjek.

Beberapa penelitian terdahulu yang terkait dengan terapi menulis pengalaman emosional diantaranya penelitian Susilowati (Fikri, 2012) menggunakan terapi menulis pengalaman emosional untuk menurunkan depresi pada mahasiswa tahun pertama. Penelitian ini menunjukkan bahwa terapi menulis pengalaman emosional merupakan sarana bantu diri yang terbukti efektif menurunkan depresi pada mahasiswa tahun pertama. Hasil penelitian ini juga terbukti pada kasus subjek yang mengalami depresi.

Penelitian yang serupa juga dilakukan oleh Siswanto (Fikri, 2012) yang menggunakan terapi menulis pengalaman emosional untuk menurunkan simptomsimptom depresi pada mahasiswa. Hasilnya adalah terapi menulis pengalaman emosional merupakan mekanisme proses teraupetik yang berpusat pada proses penyingkapan diri. Kaloeti (2007; Fikri 2012) juga melakukan penelitian menggunakan terapi menulis pengalaman emosional untuk mengelola stres pada penyalahguna NAPZA, dan hasil penelitian menunjukkan bahwa menulis pengalaman emosional dapat menurunkan tingkat distres karena membantu individu untuk belajar membuka diri, bersentuhan dengan diri pribadi dan mengenal emosinya dengan lebih baik.

Tulisan, dalam konteks penelitian ini, menjadi mediator antara pikiran internal subjek dan kondisi nyata dunia yang dihadapinya. Melalui tulisan subjek mampu melihat lebih jernih bagaimana bentuk situasi yang selama ini dia hadapi. Tulisan menjadi semacam bingkai pikiran yang menyatukan pikiran dan perasaan subjek yang selama ini terdisintegrasi. Hal ini sesuai dengan konsep terapi kognitifperilaku yang merekonstruksi cara berpikir individu dan membiasakan perilaku baru yang lebih adaptif. Setelah pikiran berhasil direkonstuksi, subjek memiliki pemahaman baru bahwa dia kembali menjadi manusia baru yang lebih bahagia dan Tuhan senantiasa mengampuni dosa hambaNya yang bertaubat.

\section{Simpulan}

Kesimpulan yang diperoleh dari penelitian ini adalah terapi menulis yang dilekatkan dengan pendekatan kognitif perilaku mampu merekonstruksi pikiran dan perilaku subjek, sehingga mampu lebih positif dalam memandang diri dan dunia sekitarnya. Aktivitas menulis dapat menjadi media rekonstruksi pikiran dan perasaan, sehingga subjek mampu melihat masalah yang dihadapinya dengan lebih jernih. Unsur emosional-spiritual memberikan dampak signifikan karena subjek mampu melihat bahwa Tuhan selalu ada dan tidak pernah meninggalkannya. Unsur emosionalspiritual memiliki dampak positif pada kasus depresi karena mampu memberikan harapan, sesuatu yang hilang dalam diri individu yang mengalami depresi. Saran dalam penelitian ini ditujukan kepada subjek dan peneliti berikutnya. Subjek dalam kasus ini perlu meneruskan perilaku adaptif seperti 
menulis dan merefleksikan pengalamannya dalam media tertentu. Saran kedua adalah penelitian ini menggunakan subjek kasus tunggal. Oleh karena itu, peneliti berikutnya diharapkan dapat menggunakan teknik ini pada kasus serupa dalam jumlah responden yang lebih banyak.

\section{Daftar Pustaka}

Adz-Dzakiey, H. B. (2007). Psikologi Kenabian: Menghidupkan Potensi dan Kepribadian Kenabian dalam Diri. Yogyakarta: Beranda Publishing.

Davey, G. (2008). Psychopathology: Research, Assessment, and Treatment in Clinical Psychology. United Kingdom: Blackwell Publishing

Dobson, S., \& Dozois, J.A. (2008). Risk Factors in Depression. Amsterdam: Sacademic Press Publication.

Fikri, H. T. (2012). Pengaruh Menulis Pengalaman Emosional dalam Terapi Ekspresif terhadap Emosi Marah pada Remaja. Jurnal Humanitas vol IX no 2 Agustus 2012.

Ismail, I. R., \& Siste, K. (2013). “Gangguan Depresi”. Dalam Sylvia D. Elvira dan Gitayanti Hadikusumo (para editor). 2013. Buku Ajar Psikiatri Edisi Kedua. 2013. Jakarta: Badan Penerbit Fakultas Kedokteran Universitas Indonesia.

Kaplan, H. I \& Sadock, B. (1997). Sinopsis Psikiatri Ilmu Pengetahuan Perilaku Psikiatri Klinis Ed. Ketujuh Jilid I (penerjemah Widjaja Kusuma). New York: New York University Medical Center.

Kazdin, A. E. (2010). Research Design in Clinical: $4^{\text {th }}$ Edition. Boston: A
Pearson Education Company.

Newman, W. L. (2003). Social Research Methods: Qualitative and Quantitative Approach (5 ${ }^{\text {th }}$ Edition). Boston: Pearson Education.

O'Hea, E. (2008). The Use of Cognitive Behavioral Therapy in The Treatment of Depression for Individual with Congestive Heart Failure. Journal of Springer Science ed 14 pg 13-20.

Pennebaker, J. W. (1997). Writing About Emotional Experiences as A Therapeutic Process. Journal of Psychological Science Vol 8 no 3 1997.

Qonitatin, N., Widyawati, S., \& Asih, G. Y. (2011). Pengaruh Katarsis dalam Menulis Ekspresif sebagai Intervensi Depresi Ringan pada Mahasiswa. Jurnal Psikologi Undip vol 9 no 1 April 2011.

Rosdaniar. (2012). Efektivitas Terapi Pemaafan dengan Dzikir sebagai Alternatif Terapi untuk Menurunkan Tingkat Distres Pada Istri sebagai Korban Perselingkuhan Antara Suami dan Ibu Kandungnya: Sebuah Studi Kasus. Tesis dari Magister Psikologi Profesi Universitas Islam Indonesia (tidak diterbitkan).

Santrock, J. W. (2002). Perkembangan Masa Hidup. Terjemahan dari Life Span Development, alih Bahasa Juda Damanik dan Achmad Chusairi, jilid I edisi kelima Jakarta: Erlangga.

Spiegler, M. D \& Guevremont, D.C. (2010). Contemporary Behavior Therapy Fifth Edition. USA: Cengage Learning. 